\title{
Valorisation of sugarcane bagasse ash (SCBA) with high quartz content as pozzolanic material in Portland cement mixtures
}

\author{
A.M. Pereira ${ }^{\mathrm{a}}$, J.C.B. Moraes ${ }^{\mathrm{a}}$, M.J.B. Moraes ${ }^{\mathrm{a}}$, J.L. Akasaki ${ }^{\mathrm{a}}$, M.M. Tashima ${ }^{\mathrm{a}}$, L. Soriano ${ }^{\mathrm{b}}$, \\ J. Monzób ${ }^{\mathrm{b}}$ J. Payáb $₫$. \\ a. Universidade Estadual Paulista (UNESP), Faculdade de Engenharia, Ilha Solteira. MAC - Grupo de Pesquisa em Materiais \\ Alternativos de Construção. (São Paulo, Brasil) \\ b. ICITECH - Instituto de Ciencia y Tecnología del Hormigón, GIQUIMA group, Universitat Politècnica de València \\ (Valencia, Spain) \\ $\triangle$ jjpaya@cst.upv.es
}

\author{
Received 20 January 2017 \\ Accepted 24 July 2017 \\ Available on line 20 April 2018
}

\begin{abstract}
Portland cement (OPC) production is one of the most contaminating greenhouse gas producing activities. In order to reduce OPC consumption, several alternatives are being assessed, and the use of pozzolanic material is one of them. This paper presents study on the reactivity of sugarcane bagasse ash (SCBA), a residue from sugarcane industry, as a pozzolanic material. In order to evaluate SCBA reactivity, it was mixed in pastes with hydrated lime and OPC, which were microstructurally characterised. These studies showed that SCBA presents some pozzolanic characteristics. Studies on mortars in which OPC was replaced by SCBA in the range $10-30 \%$ were also carried out. Replacement in the range 15-20\% yielded the best behaviour in terms of compressive strength. Finally, it can be concluded this ash could be valorised despite its relative low pozzolanic reactivity.
\end{abstract}

KEYWORDS: Active addition; Compressive strength; Mortar; Pozzolane; Thermal analysis.

Citation/Citar como: Pereira, A.M.; Moraes, J.C.B.; Moraes, M.J.B.; Akasaki, J.L.; Tashima, M.M.; Soriano, L.; Monzó, J.; Payá, J. (2018) Valorisation of sugarcane bagasse ash (SCBA) with high quartz content as pozzolanic material in Portland cement mixtures. Mater. Construcc. 68 [330], e153. https://doi.org/10.3989/mc.2018.00617

RESUMEN: Valorización de la ceniza de bagazo de azúcar (SCBA) con alto contenido de cuarzo como material puzolánico en mezclas de cemento Portland. La producción de cemento Portland (OPC) presenta una elevada emisión de $\mathrm{CO}_{2}$. Con el objeto de reducir el consumo de OPC, se están evaluando algunas alternativas, y el uso de materiales puzolánicos es una de ellas. En este trabajo se presenta el estudio de la reactividad de la ceniza de bagazo de caña de azúcar (SCBA) como material puzolánico, un residuo procedente de la industria de la caña de azúcar. Al objeto de evaluar la reactividad de SCBA, se realizaron pastas con cal hidratada y con OPC, las cuales fueron caracterizadas microestructuralmente. Estos estudios mostraron que SCBA presenta una cierta característica puzolánica. Se llevaron a cabo estudios en morteros en los que OPC se sustituyó por SCBA en el intervalo de 10-30\%. La sustitución en el intervalo $15-20 \%$ produjo el mejor comportamiento en términos de resistencia a compresión. Finalmente, se puede concluir que esta ceniza puede ser valorizada a pesar de su baja reactividad puzolánica.

PALABRAS CLAVES: Adición activa; Resistencia a la Compresión; Mortero; Puzolana; Análisis térmico.

ORCID ID: A.M. Pereira (http://orcid.org/0000-0001-6189-6873); J.C.B. Moraes (http://orcid.org/0000-0001-68710023); M.J.B. Moraes (http://orcid.org/0000-0002-7554-1755); J.L. Akasaki (http://orcid.org/0000-0003-1986-1196); M.M. Tashima (http://orcid.org/0000-0003-0885-9293); L. Soriano (http://orcid.org/0000-0002-5749-4609); J. Monzó (http://orcid.org/0000-0002-3657-3076); J. Payá (http://orcid.org/0000-0001-7425-5311)

Copyright: (C) 2018 CSIC. This is an open-access article distributed under the terms of the Creative Commons Attribution 4.0 International (CC BY 4.0) License. 


\section{INTRODUCTION}

In recent years, Portland cement consumption has become an issue of concern related to environmental problems. In 2015, its worldwide production was over 4.6 billion tonnes (1). To produce 1 tonne of Portland cement, is necessary to use 2.8 tonnes of raw materials (2), and 0.8 tonnes of $\mathrm{CO}_{2}$ are emitted (3). Moreover, $5-8 \%$ of global $\mathrm{CO}_{2}$ emission is related to Portland cement production $(4,5)$. These numbers have motivated research around the world into reducing the consumption of Portland cement, and the use of pozzolanic material is one of the solutions aimed at achieving this objective.

Pozzolans are siliceous or silico-aluminous materials, which do not themselves harden when mixed with water, but when calcium hydroxide is present in the mixture, they react and form cementing products similar to those formed during Portland cement hydration (6). The technological advantages of using pozzolanic materials lie in the enhancement of the mechanical properties and durability of blended Portland cement (7-9). The environmental advantages of using pozzolans extend beyond the reduction of Portland cement consumption, since the most common pozzolanic materials now used are residues from industry (silica fume and fly ash (10-12)), agroindustry (rice husk ash $(13,14)$ ) and others (15). The current study investigates the valorisation of another agroindustry residue sugarcane bagasse ash (SCBA).

Sugarcane bagasse is a well characterized by-product from the production of alcohol and sugar (16). Since the bagasse presents a substantial calorific value of over $4,000 \mathrm{kcal} / \mathrm{kg}(17)$, it is used as biomass in order to generate energy. After this procedure sugarcane bagasse ash is obtained. A problem related to this residue is the increase in the sugarcane production in recent years and, consequently, the production of a larger quantity of waste. Brazil is the largest producer of sugarcane in the world (18), yielding 736.1 million tonnes in 2014 , which represents an increase of $154 \%$ since the start of the century (19). One quarter of the sugarcane mass harvested is bagasse (17), which means that 163.4 million tonnes of the by-product were obtained in 2014. In Brazil, the bagasse is burned in boilers that temperature (in general, from 300 to $540{ }^{\circ} \mathrm{C}$ ), pressure and capacity can vary according to the utilised equipment (20). After the bagasse passes through the burning process, it is reported that about $2.5 \%$ of its mass turns into ash $(21,22)$, which represents a large amount of residue considering that over $80 \%$ of the bagasse is burned to generate energy (23). Since this residue causes disposal problems and creates environmental problems, a suitable use of this waste as pozzolanic material in blended Portland cements is being assessed by the scientific community.
Partial replacement of Portland cement with SCBA has technological and environmental benefits. Some authors studied SCBA as a pozzolanic material, and showed that the residue presents good pozzolanic activity $(24,25)$. In addition, a recent study simulated the use of SCBA as a partial replacement for the clinker in the Portland cement production and concluded that $\mathrm{CO}_{2}$ emissions would be reduced by 519.3 kilotonnes per year (26). These works provide motivation for the use of SCBA in civil construction and research into achieving a pozzolan with suitable properties.

The key to obtaining SCBA with good pozzolan activity is the calcination temperature (27). In addition, the presence of soil contamination (mainly quartz) in the bagasse has a key role in the pozzolanic activity of the ash (24). Therefore, this paper presents the study of an ash obtained from an autocombustion process of high quartz content bagasse with no temperature control. The SCBA obtained from this procedure was physically and chemically characterised. Its pozzolanic activity was assessed in pastes through FTIR, TG analysis, Frattini test and SEM studies, and in mortars through compressive strength development.

\section{MATERIALS AND METHODS}

\subsection{Materials}

Sugarcane bagasse ash (SCBA) is the main material of this study and was obtained through an autocombustion process of the bagasse. Firstly, bagasse was collected from a sugarcane producer near of the city of Ilha Solteira (São Paulo, Brazil). Due to a high water content in the bagasse, it was dried for 24 hours in the open air until it reached $4 \%$ of humidity. The dried bagasse was then treated by an auto-combustion process without temperature control. This auto-combustion process is performed in a furnace. The procedure begins with a forced ignition of the bagasse with fire provided from a phosphorus match and bottled gas. When the bagasse starts to burn by itself, the bottle gas is disconnected from the furnace. The auto-combustion process was performed during 24 hours. The maximum temperature reached in the process was under $700^{\circ} \mathrm{C}$. The obtained ash from this process contains some unburned particles, so the material was passed through sieves to remove the unburned part. In order to increase the pozzolanic activity of SCBA, the material was milled for 50 minutes in a ball mill.

In order to assesses the pozzolanic activity of SCBA, high purity $(>95 \%)$ hydrated lime $\left(\mathrm{Ca}(\mathrm{OH})_{2}\right)$ was mixed with the pozzolan in pastes. Studies on SCBA mixed with Portland cement were carried out for pastes and mortars. The Portland cement used was the Brazilian Portland cement CPV - ARI, 
which contains more than $95 \%$ clinker and has no pozzolans in its composition. The siliceous sand used in this study has a fineness modulus of 2.03 and a specific gravity of $2590 \mathrm{~kg} / \mathrm{m}^{3}$.

\subsection{Methods}

\subsubsection{Physical and chemical characterisation of $S C B A$}

SCBA chemical composition was carried out using X-Ray fluorescence (Philips Magix Pro XRF) in order to determine $\mathrm{SiO}_{2}$ and $\mathrm{Al}_{2} \mathrm{O}_{3}$ percentages, important oxides for characterisation of pozzolanic materials $(6,7)$. Mineralogy of SCBA was carried out using X-Ray diffraction (Seifert TT X-Ray Diffractometer) using $\mathrm{Cu}-\mathrm{K} \alpha$ radiation and a Ni filter, with a voltage of $40 \mathrm{kV}$ and current intensity of $20 \mathrm{~mA}$. The test was performed in the $2 \theta$ range of $5-60^{\circ}$ with a step of $0.02^{\circ}$ and step time of 2 s/step. The efficiency of the milling process was assessed through particle size studies. The mean particle diameter $\left(D_{\text {mean }}\right)$, median particle diameter $\left(D_{50}\right)$ and ninety percent passing size $\left(D_{90}\right)$ were obtained by means of a Malvern Instruments Mastersizer 2000. SEM images (JEOL JSM-6300 scanning electron microscope) were taken in order to obtain the morphology of the SCBA particles.

\subsubsection{Microstructural studies: preparation of pastes and experimental techniques}

Studies on pastes were carried out in order to evaluate the pozzolanic activity of the material. The studied hydrated lime/SCBA paste $(\mathrm{CH} / \mathrm{SCBA})$ presented a proportion of hydrated lime:SCBA:water of 3:7:10 by mass. For Portland cement/SCBA pastes (OPC/SCBA), the water/binder proportion was 0.50 (with binder being the sum of OPC and SCBA in mass), and five different replacements of OPC by SCBA (in mass) were assessed: $0 \%$ (control), 15\%, $25 \%, 33 \%$ and $50 \%$. Curing conditions for both types of pastes were performed at $20^{\circ} \mathrm{C}$ in a relative humidity (RH) higher than $95 \%$.

The following experimental techniques were used to characterise the microstructure of the pastes: Fourier transform infrared spectroscopy - FTIR (only CH/SCBA paste was assessed), thermogravimetric analysis - TGA, Frattini test and scanning electron microscopy - SEM (both CH/SCBA and OPC/SCBA pastes were assessed). FTIR tests were carried out in the wavenumber range of 400 to 4000 $\mathrm{cm}^{-1}$ using a FTIR Bruker TENSOR 27. TGA tests were performed using a Mettler-Toledo TGA 850, in $100 \mu \mathrm{L}$ sealed pin-holed aluminium crucibles in the temperature range $35-600^{\circ} \mathrm{C}$ at a heating rate of $10^{\circ} \mathrm{C} / \mathrm{min}$ in an $\mathrm{N}_{2}$ atmosphere $(75 \mathrm{~mL} / \mathrm{min}$ gas flow). Frattini test was carried out according to UNE-EN 196-5 (28). SEM images of the fractured surface of the samples were obtained using a JEOL JSM-6300 scanning electron microscope.

$\mathrm{CH} / \mathrm{SCBA}$ pastes were assessed after 3, 7, 28 and 90 days of curing for FTIR and after 90 days only for TGA and SEM. For OPC/SCSA pastes, TGA studies were carried out after 90 days of curing; Frattini test was carried out for SCBA replacement of 25,33 and $50 \%$ for 8 and 15 days; and for SEM, $33 \%$ replaced paste cured for 28 days was analysed.

\subsubsection{Compressive strength and workability of mortars}

The compressive strength of mortars was assessed using an EMIC Universal Machine with a 200-tonne load limit. For this test, five replacement percentages of OPC by SCBA were studied: $0 \%$ (control), $10 \%, 15 \%, 20 \%$ and $30 \%$. The water/ binder ratio was 0.50 , and the binder to sand ratio was $1: 2.5$. Specimens were moulded in cubic moulds of $50 \times 50 \times 50 \mathrm{~mm}^{3}$, and cured for 3, 7, 28, 56 and 90 days at $25^{\circ} \mathrm{C}$ with $\mathrm{RH}$ higher than $95 \%$ until the compressive strength test. Before moulding the specimens, their workability were assessed following the Brazilian standard NBR 7215/1996 (Flow table test) (29).

\section{RESULTS AND DISCUSSION}

\subsection{SCBA characterisation}

The XRF results for SCBA are summarised in Table 1. The material presents a high percentage of $\mathrm{SiO}_{2}(78.6 \%)$ and low percentages of $\mathrm{Al}_{2} \mathrm{O}_{3}$ and $\mathrm{Fe}_{2} \mathrm{O}_{3}(4.5 \%$ and $4.9 \%$, respectively), which gives a siliceous characteristic to the SCBA. The sum of these three oxides (88\%) is in accordance with the standard for pozzolans, ASTM C-618 (31), which requires more than $70 \%$. The LOI in the ash presented a lower value $(4.4 \%)$ than that required in the standard $(6 \%)$. Minor oxides, such as $\mathrm{CaO}$, $\mathrm{Na}_{2} \mathrm{O}, \mathrm{K}_{2} \mathrm{O}$ and $\mathrm{SO}_{3}$ were also obtained. The presence of $\mathrm{SO}_{3}(0.7 \%)$ was in accordance with the standard maximum $(5 \%)$. The SCBA in this research presented a similar chemical composition to other ashes from other studies $(24,25)$.

Figure 1 shows XRD pattern of the SCBA. In the enlarged part of the figure, the deviation in the

TABLE 1. Chemical composition of SCBA by percentage

\begin{tabular}{cccccccccc}
\hline $\mathbf{S i O}_{2}$ & $\mathbf{A l}_{2} \mathbf{O}_{3}$ & $\mathbf{F e}_{2} \mathbf{O}_{3}$ & $\mathbf{C a O}$ & $\mathbf{N a}_{2} \mathbf{O}$ & $\mathbf{K}_{2} \mathbf{O}$ & $\mathbf{S O}_{3}$ & $\mathbf{C l}$ & Others & $\mathbf{L O I}$ \\
\hline 78.6 & 4.5 & 4.9 & 1.3 & 0.2 & 2.4 & 0.7 & 0.1 & 1.9 & 4.4 \\
\hline
\end{tabular}




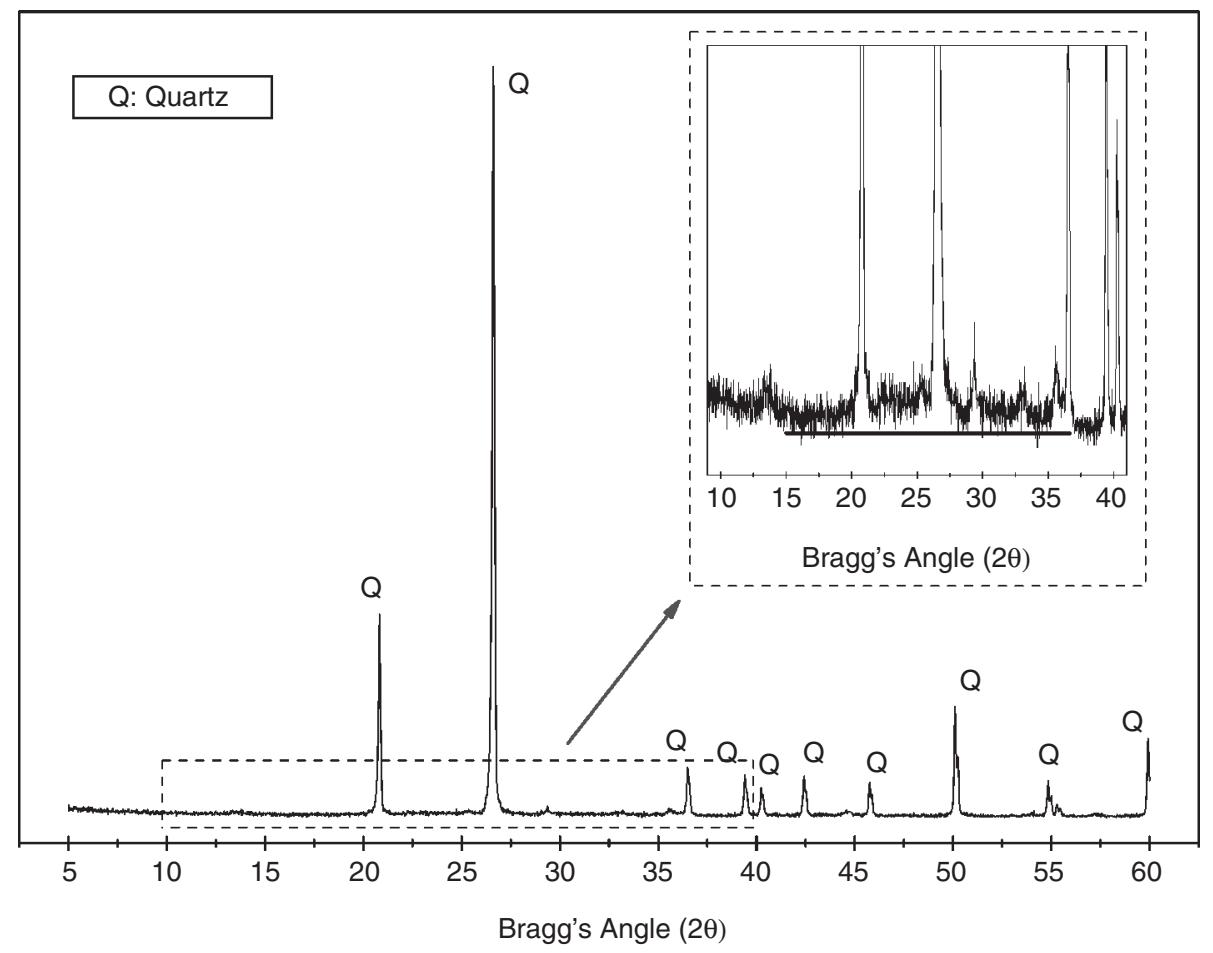

FIGURE 1. X-Ray Diffraction pattern of the SCBA.

baseline between $2 \theta=15^{\circ}$ and $2 \theta=35^{\circ}$ is characteristic of amorphous phase, typically found in pozzolanic material. The main crystalline compound of the SCBA is quartz $\left(\mathrm{SiO}_{2}\right.$, PDF Card \#331161), which is attributed to the sand from the soil adhering to the bagasse during the harvesting process. Cordeiro et al. (2009) reported that even if the bagasse passes through a washing process, adhered sand is still the major compound in the inorganic matter fraction in the ash (24). Cristobalite and tridymite were not found as mineral phases in SCBA, suggesting that the combustion process was appropriate to yield amorphous compounds from the silica gel contained in the tissues of the plant. The insoluble residue (in percentage) in the SCBA was determined by treating the ash with $4 \mathrm{M} \mathrm{KOH}$ solution in boiling conditions for 4 minutes. The result of this test was $75 \%$, indicating that the crystalline phase is insoluble in alkaline conditions. This result suggests that poor pozzolanic reactivity would be likely for this ash.

Particle size studies were carried out in order to evaluate the influence of the milling process. The SCBA sample before milling presented a $\mathrm{D}_{\text {mean }}, \mathrm{D}_{50}$ and $\mathrm{D}_{90}$ of $87.9 \mu \mathrm{m}, 52.4 \mu \mathrm{m}$ and $202.8 \mu \mathrm{m}$, respectively. For the SCBA sample after a milling time of 50 minutes, the $D_{\text {mean }}, D_{50}$ and $D_{90}$ values were 34.6 $\mu \mathrm{m}, 25.1 \mu \mathrm{m}$ and $82.3 \mu \mathrm{m}$, respectively. These results showed a reduction of approximately $60 \%$ in the particle size of the SCBA, which probably improves its pozzolanic activity. Figure 2 shows SEM images comparing SCBA before and after the milling process. Figure $2 \mathrm{a}$ and $2 \mathrm{~b}$ shows the SCBA before milling process, presenting larger particles than SCBA after the milling process, shown in Figure 2c and 2d. In general, SCBA both before and after the milling process presents irregular particles.

\subsection{FTIR, TGA, Frattini and SEM studies}

FTIR spectra for SCBA and CH/SCBA paste are shown in Figure 3. The main vibrations of the SCBA are the Si-O vibrations at 1091, 1040, 777, 694 and $447 \mathrm{~cm}^{-1}$. At all curing ages for CH/SCBA paste, the main vibrations are $3641 \mathrm{~cm}^{-1}(\mathrm{O}-\mathrm{H}$ vibration); 1441 and $873 \mathrm{~cm}^{-1}$, (O-C-O vibration); 1091 , $1040,945,777,694$ and $447 \mathrm{~cm}^{-1}$ (Si-O vibration) (31). Firstly, it is notable that the vibration bands at 1040 and $3641 \mathrm{~cm}^{-1}$ decreased with the curing age, a result of the pozzolanic reaction between the amorphous $\mathrm{SiO}_{2}$ from the SCBA and the $\mathrm{Ca}(\mathrm{OH})_{2}$. The cementitious products of this reaction are identified at the vibration band $945 \mathrm{~cm}^{-1}$, and this band increased with the curing age. According to Yu et al. (1999), bands in the $950-970 \mathrm{~cm}^{-1}$ are attributed to Si-O vibrations in C-S-H gel (32). Probably in the case of this paper, the lower energy band was due to the high $\mathrm{Ca} / \mathrm{Si}$ ratio and the presence of $\mathrm{Al}$ in the C-S-H gel structure. It is important to mention that the SCBA did not consume all of the hydrated lime, since the vibration band at $3641 \mathrm{~cm}^{-1}$ remained after 90 days of curing. The vibration bands of $\mathrm{Si}-\mathrm{O}$ at 
(a)

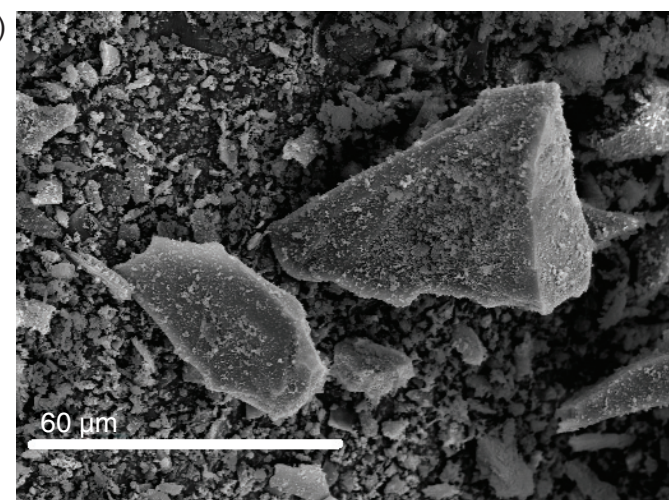

(c)

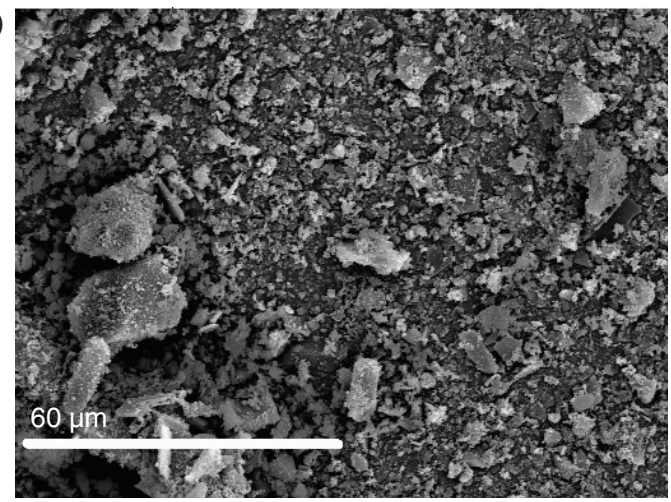

(a)

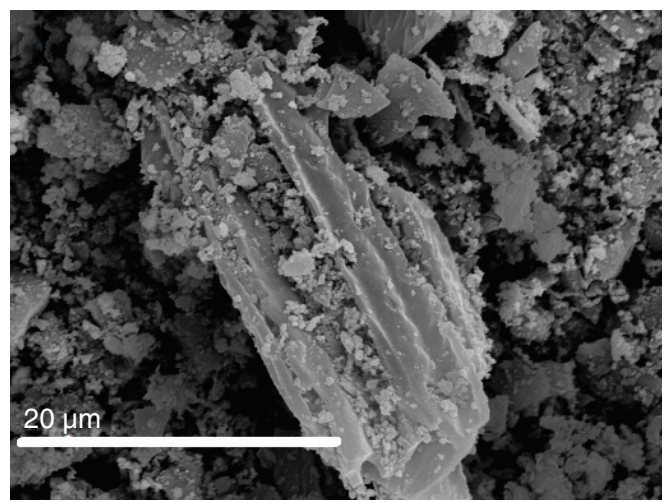

(c)

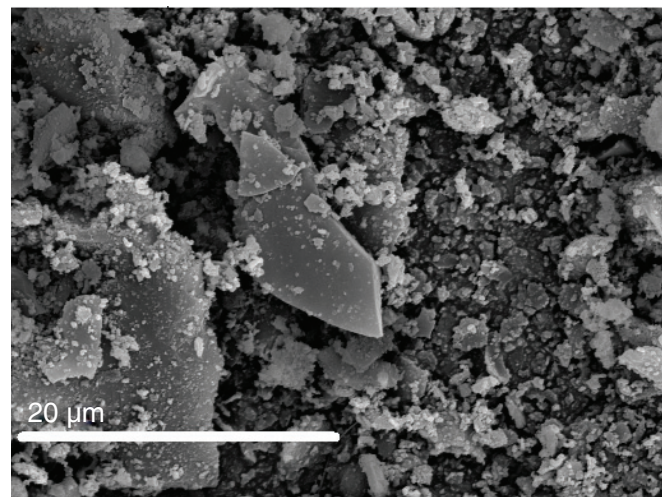

FIGURE 2. SEM images of SCBA: a) and b) before milling process; c) and d) after a milling time of 50 minutes.

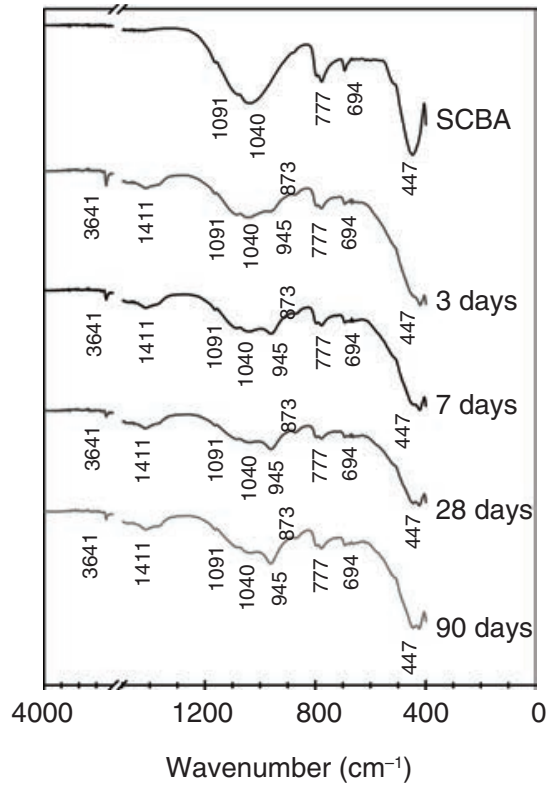

FIGURE 3. FTIR spectra for SCBA and CH/SCBA pastes after 3, 7, 28 and 90 days of curing.

1091, 777, 694 and $447 \mathrm{~cm}^{-1}$ remained unchanged at all curing ages, which means these vibrations are attributed to the quartz present in the SCBA. The other vibration bands, at 1441 and $873 \mathrm{~cm}^{-1}$, are related to the carbonation of the sample and/or impurities of $\mathrm{CaCO}_{3}$ in the hydrated lime.
Derivative thermogravimetric (DTG) curves from TGA for CH/SCBA and OPC/SCBA pastes after 90 days of curing are shown in Figure 4. The mass losses between 125 and $250^{\circ} \mathrm{C}$ are related to the dehydration of cementitious products. The first mass losses, between 125 and $175^{\circ} \mathrm{C}$, are related to the dehydration of the C-S-H gel and ettringite (33), the second mass loss, between 200 and $250^{\circ} \mathrm{C}$, corresponds to dehydration of probably hydrated gehlenite and other calcium aluminosilicate hydrates $(34,35)$. The final mass loss, between 525 and $600^{\circ} \mathrm{C}$, corresponds to dehydration of the portlandite (33).

In $\mathrm{CH} / \mathrm{SCBA}$ paste, both reaction products, $\mathrm{C}-\mathrm{S}-\mathrm{H}$ gel and probably hydrated gehlenite, were formed, because there are mass losses in the range $125-150^{\circ} \mathrm{C}$ and $200-250^{\circ} \mathrm{C}$, respectively. Hydrated gehlenite is attributed to the presence of reactive aluminium in the ash. This aluminium is attributed to soil contamination of the bagasse, probably as a component of clay. The SCBA did not react with all of the hydrated lime, since there is mass loss in the range $525-575^{\circ} \mathrm{C}$ after 90 days of curing. These results are in agreement with the FTIR studies.

For OPC/SCBA pastes, it is notable that the mass loss related to the calcium silicate hydrate decreases with the increase of the SCBA percentage in the paste, whereas the mass loss related to the aluminium-containing hydrates increases. As expected, the mass loss related to the portlandite decreases as the amount of SCBA increases for two reasons: firstly, 


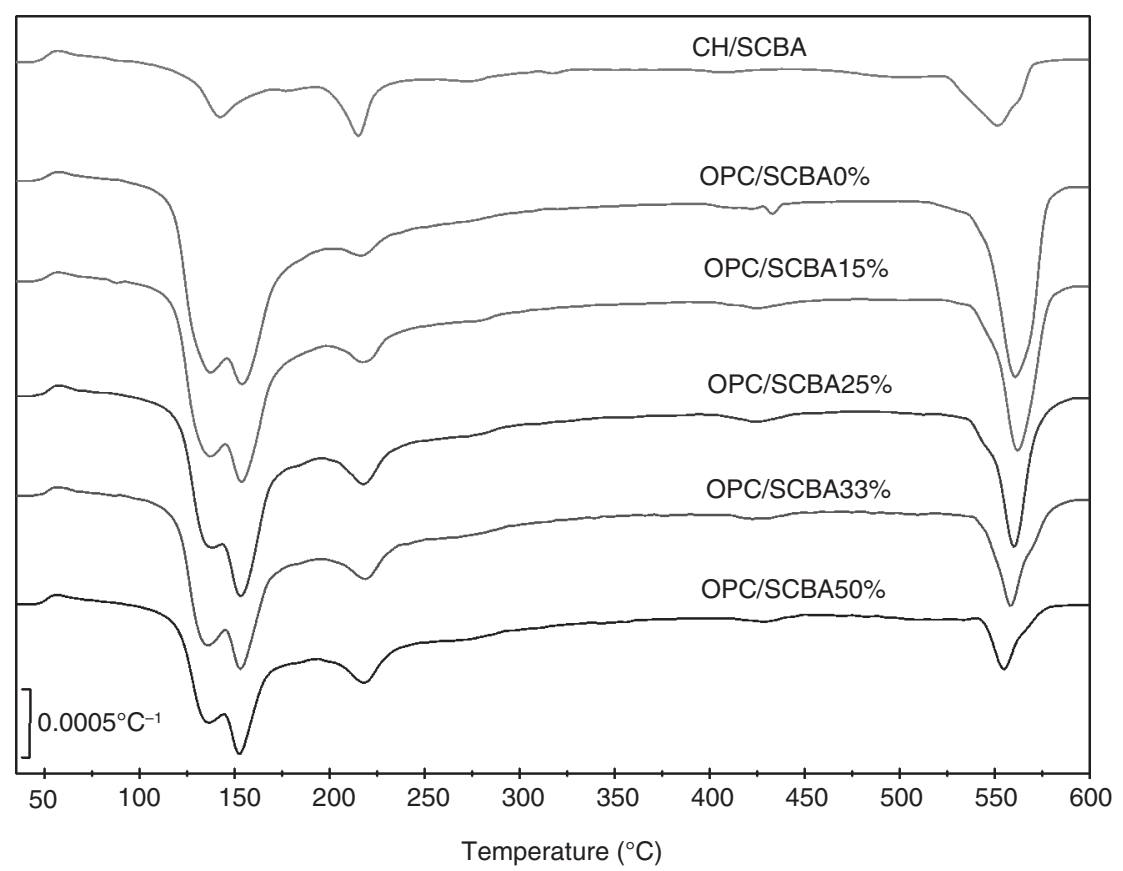

FIgURE 4. DTG curves for $\mathrm{CH} / \mathrm{SCBA}$ and OPC/SCBA pastes after 90 days of curing.

there is less Portland cement and consequently less portlandite; and secondly, the pozzolanic reaction causes portlandite consumption by the SCBA.

Table 2 summarises the mass losses of the $\mathrm{CH} /$ SCBA and OPC/SCBA pastes after 90 days of curing. Summarised mass losses are related to the dehydration of compounds from OPC hydration and pozzolanic reaction $\left(\mathrm{P}_{\mathrm{T}}\right), \mathrm{Ca}(\mathrm{OH})_{2}$ dehydration $\left(\mathrm{P}_{\mathrm{CH}}\right)$, lime fixation (percentage of hydrated lime reacted with SCBA) and lime consumption (ratio of calcium hydroxide consumed/SCBA in mass). For $\mathrm{CH} / \mathrm{SCBA}$ paste, it is notable that $60.73 \%$ of the hydrated lime was consumed by the SCBA after 90 days of curing; and the lime consumption was 0.26. This value is noticeable taking into account the high percentage of insoluble residue in the SCBA.

In OPC/SCBA pastes, the $\mathrm{P}_{\mathrm{T}}$ value decreases with increasing SCBA percentage in the paste, as a result of a reduction in the formation of hydrated products. However, $\mathrm{P}_{\mathrm{T}}$ values for SCBA containing pastes were higher than the product of $\mathrm{P}_{\mathrm{T}}$ for OPC paste multiplied by the percentage of cement: this behaviour means that there is a significant contribution from reactivity of SCBA. Lime fixation increased with the SCBA percentage and for the highest OPC replacement (OPC/SCBA50\%) there was remaining portlandite. When comparing this result with the reported lime fixation in similar OPC/fly ash mixtures (36), it can be concluded that the pozzolanic reactivity of the studied SCBA was lower than that found for fly ashes. The highest value of lime consumption for SCBA pastes was 0.19 , found for the OPC/SCBA $25 \%$ mixture, suggesting that the optimum replacement percentage would be in the $20-30 \%$ range.

Frattini results are represented in the Figure 5 for OPC/SCBA pastes after 8 and 15 days. For both testing ages, it is noticed that only the OPC/ SCBA $50 \%$ mixture was placed below the saturation curve. In the other hand, OPC/SCBA mixtures of 25 and $33 \%$ are found above the saturation. These results showed a low pozzolanic reactivity of the SCBA in early ages. In the other hand, TG and FTIR studies showed some pozzolanic activity in later curing time.

Figures 6 shows SEM images of $\mathrm{CH} / \mathrm{SCBA}$ pastes after 90 days of curing. In Figure 6a, a general view of the matrix formed from pozzolanic reaction is shown, with particles of quartz from unreacted SCBA. In Figure 6b, detail is shown of an area in which pozzolanic products are observed: different morphologies were identified for hydration products.

SEM images of OPC/SCBA33\% after 28 days of curing are shown in Figure 7. A general view of the matrix formed from OPC and pozzolanic reactions is shown in Figure 7a. Typical C-S-H gel and ettringite needles were observed (Figure 7b). Quartz particles from SCBA are embedded in hydration products (Figure 7c). 
Valorisation of sugarcane bagasse ash (SCBA) with high quartz content as pozzolanic material in Portland cement mixtures $\bullet 7$

TABLE 2. Total compound dehydration $\left(\mathrm{P}_{\mathrm{T}}\right), \mathrm{Ca}(\mathrm{OH})_{2}$ dehydration $\left(\mathrm{P}_{\mathrm{CH}}\right)$, lime fixation and lime consumption of the CH/SCBA and OPC/SCBA pastes after 90 days of curing

\begin{tabular}{llcccc}
\hline Specimen & & $\mathbf{P}_{\mathrm{T}}(\mathbf{\%})$ & $\mathbf{P}_{\mathrm{CH}}(\mathbf{\%})$ & Lime Fixation (\%) & Lime consumption* \\
\hline Hydrated lime paste & CH/SCBA & 8.57 & 1.55 & 60.73 & 0.26 \\
Portland cement pastes & OPC/SCBA0\% & 20.84 & 3.06 & - & - \\
& OPC/SCBA15\% & 19.02 & 2.33 & 10.42 & 0.11 \\
& OPC/SCBA25\% & 17.75 & 1.54 & 32.90 & 0.19 \\
& OPC/SCBA33\% & 16.26 & 1.31 & 36.10 & 0.14 \\
& OPC/SCBA50\% & 13.43 & 0.92 & 39.87 & 0.08 \\
\hline
\end{tabular}

$* \mathrm{~g}$ of fixed $\mathrm{Ca}(\mathrm{OH})_{2} / \mathrm{g}$ of $\mathrm{SCBA}$

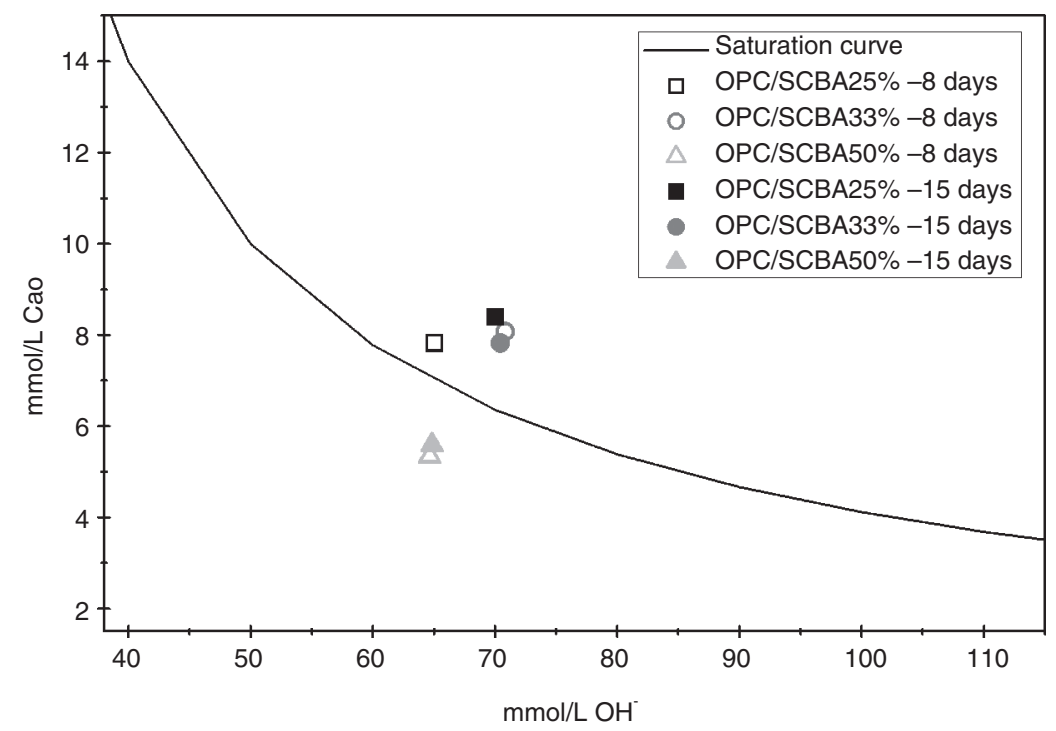

Figure 5. Frattini test results for OPC/SCBA pastes after 8 and 15 days.

(a)

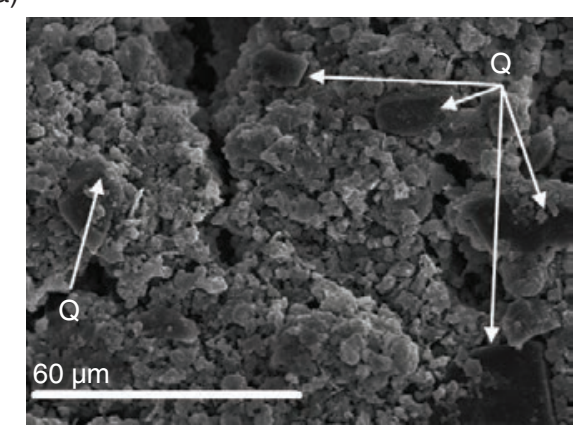

(b)

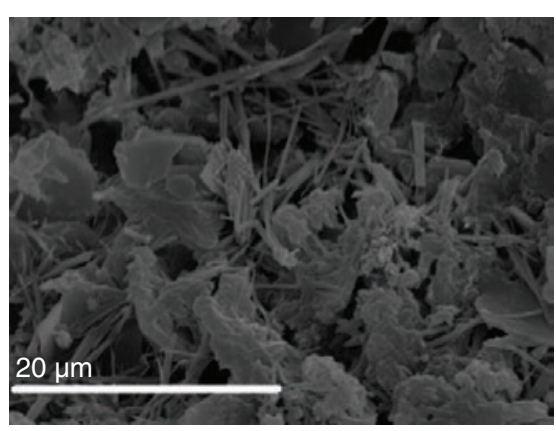

FIGURE 6. SEM images of CH/SCBA pastes after 90 days of curing (Key: Q, quartz).

\subsection{Workability and compressive strength of mortars}

SCBA reactivity in mortars was assessed by partially replacing the Portland cement at a proportion of $0 \%$ (control), $10 \%, 15 \%, 20 \%$ and $30 \%$ by mass. Table 3 summarises the results obtained from studies on workability and strength. In general terms,
SCBA did not modify the workability of mortars when the replacement was in the range 10-20\%, whereas for the highest replacement percentage, a reduction in workability was observed.

With respect to the compressive strength results, all mortars presented increasing values with the increasing curing time. Mortars containing SCBA presented 
(a)

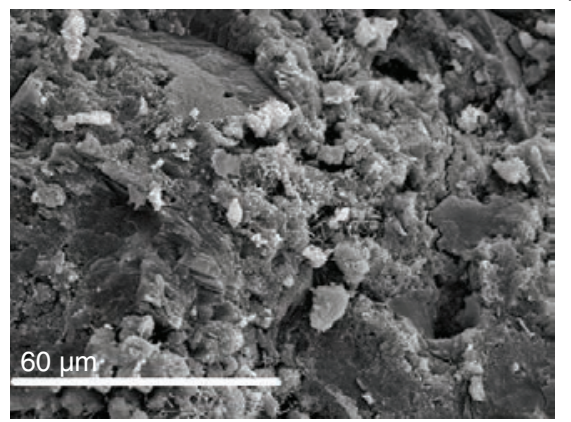

(b)

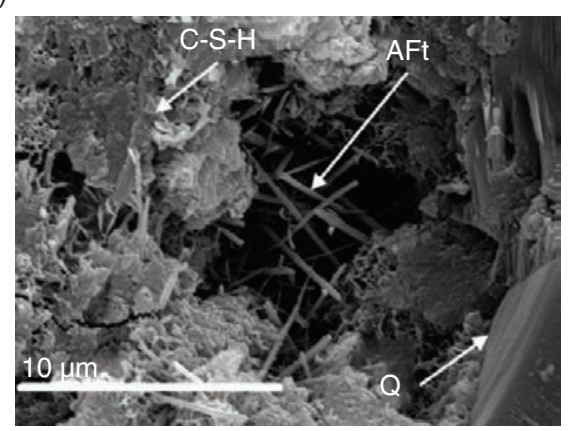

(c)

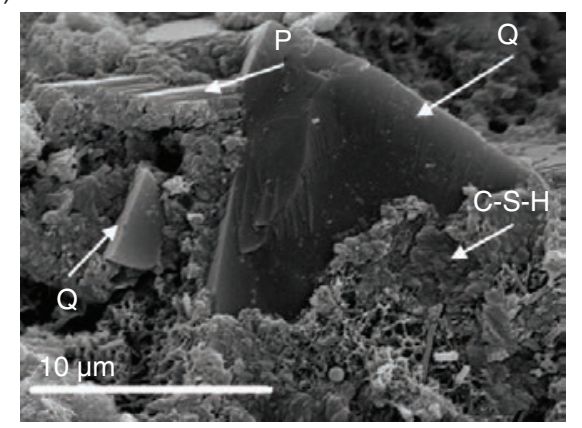

FIGURE 7. SEM images of OPC/SCBA pastes after 28 days of curing (Keys: Q, quartz; P, portlandite; C-S-H, calcium silicate hydrate; AFt, ettringite).

TABLE 3. Workability and compressive strength of mortars

\begin{tabular}{lccccccc}
\hline & \multirow{2}{*}{$\begin{array}{c}\text { Flow table } \\
\text { test }(\mathbf{m m})\end{array}$} & $\mathbf{3}$ days & $\mathbf{7}$ days & $\mathbf{2 8}$ days & $\mathbf{5 6}$ days & $\mathbf{9 0}$ days & $\mathbf{b}_{\mathbf{p}} / \mathbf{b}_{\text {ctr }}$ \\
\cline { 3 - 7 } Specimen & $294 \pm 4$ & $33.1 \pm 2.0$ & $43.7 \pm 1.2$ & $45.0 \pm 2.0$ & $56.9 \pm 2.4$ & $58.0 \pm 3.0$ & - \\
\hline SCBA0 $\%$ & $280 \pm 4$ & $29.5 \pm 2.0$ & $37.3 \pm 0.8$ & $39.0 \pm 1.6$ & $47.0 \pm 1.8$ & $47.2 \pm 2.9$ & 0.72 \\
SCBA10\% & $298 \pm 2$ & $27.2 \pm 0.7$ & $32.0 \pm 1.3$ & $34.6 \pm 1.9$ & $46.0 \pm 2.7$ & $46.5 \pm 2.5$ & 0.83 \\
SCBA15\% & $294 \pm 4$ & $23.9 \pm 0.3$ & $30.0 \pm 1.7$ & $34.6 \pm 1.8$ & $42.4 \pm 2.0$ & $43.0 \pm 2.0$ & 0.82 \\
SCBA20\% & $251 \pm 3$ & $24.3 \pm 1.5$ & $32.2 \pm 0.5$ & $35.7 \pm 1.5$ & $37.7 \pm 1.9$ & $38.1 \pm 1.7$ & 0.55 \\
SCBA30\% & & & & & & &
\end{tabular}

compressive strengths significantly below the corresponding control ones at all curing ages. TGA studies showed that the pozzolanic contribution of SCBA was very limited, and this behaviour is confirmed in terms of compressive strength development. The compressive strength values decrease with the amount of SCBA in the mixtures, with the result that SCBA10\% and SCBA $15 \%$ presented the best results for mortars with pozzolan. After 90 days of curing, both mortars reached $80 \%$ of the compressive strength of the control mortar. For the highest replacement (SCBA30\%), the achieved strength was only $65 \%$ at the same curing age, revealing the limited reactivity of the pozzolan.

In order to determine the contribution of SCBA to the strength gain, a correlation between curing time ( $\mathrm{t})$ and compressive strength values $\left(\mathrm{R}_{\mathrm{c}}\right)$ according to the equation $\mathrm{R}_{\mathrm{c}}=\mathrm{a}+\mathrm{b} \log (\mathrm{t})$, were calculated. The slope of the equation, $b$, represents the gain of compressive strength in a determined curing age interval of the studied mortar. The slope of the control mortar is named $b_{c t r}$ and the slope of mortar with SCBA is named $b_{p}$. The relative slope of a mortar with SCBA is calculated by the ratio $b_{p} /$ $\mathrm{b}_{\mathrm{ctr}}$ (see Table 3 ).

SCBA $15 \%$ and SCBA20\% showed the highest values for the $b_{\mathrm{p}} / b_{\text {ctr }}$ ratio within the SCBA mortars, which means at those replacement percentages, the SCBA mortars gained more compressive strength than SCBA $10 \%$ and SCBA $30 \%$ mortars. It can be concluded that for this pozzolan, which contains a large proportion of inert particles, a suitable replacement percentage is in the range $15-20 \%$. 


\section{CONCLUSIONS}

A pozzolanic activity study of sugarcane bagasse ash (SCBA) with high quartz content was carried out in this paper. This ash was obtained from a new method of auto-combustion process of the sugarcane bagasse. The SCBA obtained from this process was characterized: a high presence of $\mathrm{SiO}_{2}$ $(78.6 \%)$ and insoluble phases $(75 \%)$. In addition, the milling process used to reduce the particle size of the SCBA showed to be suitable, since reduced its particle size in $60 \%$. Studies on CH/SCBA and OPC/SCBA pastes were assessed by FTIR (only for hydrated lime pastes), TGA, Frattini test and SEM analyses. In CH/SCBA pastes, FTIR and TGA studies showed that the pozzolan could not fix all the lime in the proportion studied (3:7), presenting a lime fixation of $60.73 \%$ after 90 days of curing; SEM images showed presence of C-S-H gel from pozzolanic reaction. TG studies on OPC/ SCBA pastes showed lime fixation in the range of $10.42-39.87 \%$ after 90 days of curing and, based on the lime consumption parameter, the best replacement percentage of OPC by SCBA is in the range $20-30 \%$ with a value of 0.19 for pozzolan percentage of $25 \%$. Frattini test results showed low pozzolanic activity at early ages. The SCBA was studied in mortars replacing partially the Portland cement in the range $10-30 \%$ by means of workability and compressive strength measurements. In general, the workability did not show changes for $0-20 \%$ range of replacement. The SCBA containing mortars presented lower strength values than the control in all curing ages. SCBA mortars in the replacement range $15-20 \%$ gained more compressive strength with curing time than other replacement percentages studied, showing a $b_{p} / b_{\text {ctr }}$ value over than 0.80 .

\section{ACKNOWLEDGMENT}

The authors would like to thank the Ministerio de Educación, Cultura y Deporte of Spain (Cooperación Interuniversitaria Program with Brazil, Project PHB-2011-0016-PC), CAPES-Brazil (Project CAPES/DGU No. 266/12), CNPq (Project 401724/2013-1) and Electron Microscopy Service of the Universitat Politècnica de València.

\section{REFERENCES}

1. World cement production. CEMBUREAU - The European Cement Association Website; https://cembureau.eu/media/ 1503/2015activityreport_cembureau.pdf

2. Guo, X.; Shi, H.; Dick, W.A. (2010) Compressive strength and microstructural characteristics of class $\mathrm{C}$ fly ash geopolymer. Cem. Concr. Compos. 32, 142-7. https://doi. org/10.1016/j.cemconcomp.2009.11.003

3. Mehta, P.K.; Monteiro, P.J.M. Concrete: Microstructure, Properties, and Materials. 3rd ed. New York: McGrawHill, (2006).
4. Mo, K.H.; Alengaram, U.J.; Jumaat, M.Z. (2016) Structural performance of reinforced geopolymer concrete members: A review, Constr. Build. Mater. 120, 251-264. https://doi.org/10.1016/j.conbuildmat.2016.05.088

5. Sharp, J.H.; Gartner, E.M.; Macphee, D.E. (2010) Novel cement system (sustainability). Session 2 of the Fred Glasser cement science symposium. Adv. Cem. Res. 22(4), 195-202. https://doi.org/10.1680/adcr.2010.22.4.195

6. BS EN 197-1. Cement-Part 1: Composition, specifications and conformity criteria for common cements. London: European Committee For Standardisation; (2011).

7. Siddique, R.; Khan, M.I. Supplementary Cementing Materials. 1st ed. Berlin: Springer, (2011).

8. Siddique, R. Waste Material and By-Products in Concrete. 1st ed. Berlin: Springer, (2008).

9. Kücükyıldırım, E. Uzal, B (2014) Characteristics of calcined natural zeolites for use in high-performance pozzolan blended cements. Constr. Build. Mater. 73, 229-34. https://doi.org/10.1016/j.conbuildmat.2014.09.081

10. Tashima, M.M.; Soriano, L.; Monzó, J.; Borrachero, M.V.; Akasaki, J.L.; Payá, J. (2014) New method to assessthe pozzolanic reactivity of mineral admixtures by means $\mathrm{pH}$ and electrical conductivity measurementsin lime:pozzolan suspensions. Mater. Construc. 64 [316], e032. https://doi. org/10.3989/mc.2014.00914

11. Wongkeo, W.; Thongsanitgarn, P.; Chaipanich, A. (2012) Compressive strength and drying shrinkage of fly ashbottom ash-silica fume multi-blended cement mortars. Mater. Des. 36, 655-62. https://doi.org/10.1016/j. matdes.2011.11.043

12. Lee, C.L.; Huang, R.; Lin, W.T.; Weng, T.L. (2012) Establishment of the durability indices for cement-based composite containing supplementary cementitious materials. Mater. Des. 37, 28-39. https://doi.org/10.1016/j. matdes.2011.12.030

13. Sinsiri, T.; Kroenhong, W.; Jaturapitakkul, C.; Chindaprasirt, P. (2012) Assessing the effect of biomass ashes with different finenesses on the compressive strength of blended cement paste. Mater. Des. 42, 424-33. https:// doi.org/10.1016/j.matdes.2012.06.030

14. Pereira, C.L.; Savastano Jr., H.; Payá, J.; Santos, S.F.; Borrachero, M.V.; Monzó, J. (2013) Use of highly reactive rice husk ash in the production of cement matrix reinforced with green coconut fiber. Ind. Crop. Prod. 49, 88-96. https://doi.org/10.1016/j.indcrop.2013.04.038

15. Paiva, H.; Velosa, A.; Cachim, P.; Ferreira, V.M. (2016) Effect of pozzolans with diferent physical and chemical characteristics on concrete properties. Mater. Construc. 66 [322], 1-12. https://doi.org/10.3989/mc.2016.01815

16. Hoi, L.W.S.; Martincigh, B.S. (2013) Sugar cane plant fibres: Separation and characterization. Ind. Crop. Prod. 47, 1-12. https://doi.org/10.1016/j.indcrop.2013.02.017

17. Hugot, E. Handbook of Cane Sugar Engineering. 3rd ed. Amsterdam:Elsevier Science Publishers, (1986).

18. Sugarcane production. FAOSTAT - Food and Agriculture Organisation of the United Nations, Statistics Division; http://www.fao.org/faostat/en/\#data/QC

19. Sugarcane production. UNICA - União da Indústria de Cana-de-Açúcar Website; http://www.unicadata.com. br/index.php?idioma $=2$

20. A Geração Termoelétrica com a Queima do Bagaço de Cana-de-Açúcar no Brasil. CONAB-Companhia Nacional de Abastecimento; http://www.agricultura.gov.br/assuntos/ sustentabilidade/agroenergia/arquivos-termoeletricacom-a-queima-do-bagaco-de-cana-de-acucar/ termoeletrica-com-a-queima-do-bagaco-de-cana-deacucar-no-brasil-safra-2009-2010.pdf

21. Cortez, L.A.B.; Gómez, E.O. (1998) A method for exergy analysis of sugarcane bagasse boilers. Braz. J. Chem. Eng. 15 [1]. https://doi.org/10.1590/S0104-66321998000100006

22. Souza, A.E.; Teixeira, S.R.; Santos, G.T.A.; Costa, F.B.; Longo, E. (2011) Reuse of sugarcane bagasse ash (SCBA) to produce ceramic materials. J. Environ. Manage. 92, 2774-80. https://doi.org/10.1016/j.jenvman.2011.06.020

23. Hofsetz, K.; Silva, M.A. (2012) Brazilian sugarcane bagasse: Energy and non-energy consumption. Biomass 
Bioenerg 46, 564-573. https://doi.org/10.1016/j.biombioe. 2012.06.038

24. Cordeiro, G.C.; Toledo Filho, R.D.; Tavares, L.M.; Fairbairn, E.M.R. (2009) Ultrafine grinding of sugar cane bagasse ash for application as pozzolanic admixture in concrete. Cem. Concr. Res. 39, 110-115. https://doi. org/10.1016/j.cemconres.2008.11.005

25. Frías, M.; Villar, E.; Savastano, H. (2011) Brazilian sugar cane bagasse ashes from the cogeneration industry as active pozzolans for cement manufacture. Cem. Concr. Compos. 33, 490-496. https://doi.org/10.1016/j. cemconcomp.2011.02.003

26. Fairbairn, E.M.R.; Americano, B.B.; Cordeiro, G.C.; Paula, T.P.; Toledo Filho, R.D.; Silvoso, M.M. (2010) Cement replacement by sugar cane bagasse ash: $\mathrm{CO}_{2}$ emissions reduction and potential for carbon credits. J. Environ. Manage. 91, 1864-1871. https://doi.org/10.1016/j.jenvman. 2010.04.008

27. Cordeiro, G.C.: Toledo Filho, R.D; Fairbairn, E.M.R. (2009) Effect of calcination temperature on the pozzolanic activity of sugar cane bagasse ash. Constr. Build. Mater. 23, 3301-3303. https://doi.org/10.1016/j. conbuildmat.2009.02.013

28. UNE-EN 196-5. Método de ensayo de cementos. Parte 5: Ensayo de puzolanicidad para los cementos puzolánicos. Madrid: Asociación Española de Normalización y Certificación - AENOR; (2011).

29. NBR 7215. Cimento Portland - Determinação da resistência à compressão. Rio de Janeiro: Associação Brasileira de Normas Técnicas - ANBT; (1996).
30. ASTM C-618. Standard Specification for Coal Fly Ash and Raw or Calcined Natural Pozzolan for Use in Concrete. Philadelphia: ASTM International; (2005).

31. Allahverdi, A.; Shaverdi, B.; Kani, E. (2010) Influence of sodium oxide on properties of fresh and hardened paste of alkali-activated blast-furnace slag. Int. J. Civ. Eng. 8, 304-314.

32. Yu, P.; Kirkpatrick, R.J.; Poe, B.; McMillan, P.F.; Cong, X. (1999) Structure of calcium silicate hydrate (C-S-H): Near-, mid-, and far-infrared spectroscopy. J. Am. Ceram. Soc. 82(3), 742-748. https://doi.org/10.1111/j.1151-2916.1999. tb01826.x

33. Moraes, J.C.B.; Akasaki, J.L.; Melges, J.L.P.; Monzó, J.; Borrachero, M.V.; Soriano, L.; Payá, J.; Tashima, M.M. (2015) Assessment of sugar cane straw ash (SCSA) as pozzolanic material in blended Portland cement: Microstructural characterisation of pastes and mechanical strength of mortars. Constr. Build. Mater. 94, 670-677. https://doi.org/10.1016/j.conbuildmat.2015.07.108

34. Murat, M. (1983) Hydration reaction and hardening of calcined clays and related minerals: II. Influence of mineralogical properties of raw-kaolinite on the reactivity of metakaolinite. Cem. Concr. Res. 11, 511-518.

35. Serry, M.A.; Taha, A.S.; El-Hemaly, S.A.S.; El-Didamony, H. (1984) Metakaolin-lime hydration products. Thermochim. Acta 79, 103-110.

36. Lorca, P.; Calabuig, R.; Benlloch, J.; Soriano, L.; Payá, J. (2014) Microconcrete with partial replacement of Portland cement by fly ash and hydrated lime addition. Mater. Des. 64, 535-541. https://doi.org/10.1016/j.matdes.2014.08.022 